\title{
BOUNDS FOR THE PERIMETER OF AN
}

\section{ELLIPSE IN TERMS OF POWER MEANS}

\section{Zai-Yin He, MiaO-Kun Wang, Yue-Ping Jiang And Yu-Ming Chu}

Abstract. In the article, we provide several precise bounds for the perimeter of an ellipse in terms of the power means, and present new bounds for the complete elliptic integral of the second kind. The given results are the improvements of some earlier results.

Mathematics subject classification (2010): 33E05, 33C75, $26 \mathrm{E} 60$.

Keywords and phrases: Perimeter, ellipse, power mean, complete elliptic integral, Gaussian hypergeometric function.

\section{REFERENCES}

[1] T.-R. HuAng, S.-Y. TAn, X.-Y. MA And Y.-M. CHU, Monotonicity properties and bounds for the complete p-elliptic integrals, J. Inequal. Appl., 2018, 2018, Paper No. 239, 11 pp.

[2] M.-K. WAng, Y.-M. ChU AND Y.-Q. Song, Asymptotical formulas for Gaussian and generalized hypergeometric functions, Appl. Math. Comput., 2016, 276, 44-60.

[3] M.-K. WANG, Y.-M. CHU AND Y.-P. JiAng, Ramanujan's cubic transformation inequalities for zero-balanced hypergeometric functions, Rocky Mountain J. Math., 2016, 46(2), 679-691.

[4] M.-K. WANG AND Y.-M. CHU, Refinements of transformation inequalities for zero-balanced hypergeometric functions, Acta Math. Sci., 2017, 37B(3), 607-622.

[5] M.-K. WANG AND Y.-M. CHU, Landen inequalities for a class of hypergeometric functions with applications, Math. Inequal. Appl., 2018, 21(2), 521-537.

[6] S.-L. QIU, X.-Y. MA AND Y.-M. CHU, Sharp Landen transformation inequalities for hypergeometric functions, with applications, J. Math. Anal. Appl., 2019, 474(2), 1306-1337.

[7] M.-K. WANG, Y.-M. CHU AND W. ZHANG, Monotonicity and inequalities involving zero-balanced hypergeometric function, Math. Inequal. Appl., 2019, 22(2), 601-617.

[8] Z.-H. YANG AND J.-F. TIAN, Convexity and monotonicity for elliptic integrals of the first kind and applications, Appl. Anal. Discrete Math., 2019, 13(1), 240-260.

[9] Z.-H. YANG AND J.-F. TIAN, Sharp inequalities for the generalized elliptic integrals of the first kind, Ramanujan J., 2019, 48(1), 91-116.

[10] C.-P. CHEN, N. ElezoviĆ AND L. VuKŠIĆ, Asymptotic expansions of integral mean of polygamma functions, Math. Inequal. Appl., 2015, 18(1), 255-266.

[11] Z.-H. YANG, W.-M. QIAN, Y.-M. CHU AND W. ZHANG, On rational bounds for the gamma function, J. Inequal. Appl., 2017, 2017, Article ID 210, 17 pages.

[12] Z.-H. YANG AND J.-F. TIAN, Monotonicity and inequalities for the gamma function, J. Inequal. Appl., 2017, 2017, Article ID 317, 15 pages.

[13] Z.-H. YANG AND J.-F. TIAN, An accurate approximation formula for gamma function, J. Inequal. Appl., 2018, 2018, Article ID 56, 9 pages.

[14] Z.-H. YANG AND J.-F. TIAN, Monotonicity and sharp inequalities related to gamma function, J. Math. Inequal., 2018, 12(1), 1-22.

[15] Z.-H. YANG AND J.-F. TIAN, Two asymptotic expansions for gamma function developed by Windschitl's formula, Open Math., 2018, 16(1), 1048-1060.

[16] Z.-H. YANG AND J.-F. TIAN, A class of completely mixed monotonic functions involving the gamma function with applications, Proc. Amer. Math. Soc., 2018, 146(11), 4707-4721.

[17] Z.-H. YANG AND J.-F. TIAN, Asymptotic expansions for the gamma function in terms of hyperbolic functions, J. Math. Anal. Appl., 2019, 478(1), 133-155. 
[18] M.-K. WANG, Y.-M. ChU, S.-L. QIU AND Y.-P. JIANG, Convexity of the complete elliptic integrals of the first kind with respect to Hölder means, J. Math. Anal. Appl., 2012, 388(2), 1141-1146.

[19] Y.-M. ChU, S.-L. QIU AND M.-K. WANG, Sharp inequalities involving the power mean and complete elliptic integral of the first kind, Rocky Mountain J. Math., 2013, 43(5), 1489-1496.

[20] Z.-H. YAnG, W.-M. QIAn, Y.-M. ChU AND W. Zhang, On approximating the arithmeticgeometric mean and complete elliptic integral of the first kind, J. Math. Anal. Appl., 2018, 462(2), $1714-1726$.

[21] Z.-H. YANG, W.-M. QIAN AND Y.-M. CHU, Monotonicity properties and bounds involving the complete elliptic integrals of the first kind, Math. Inequal. Appl., 2018, 21(4), 1185-1199.

[22] Y.-M. ChU, M.-K. WANG, S.-L. QIU AND Y.-P. Jiang, Bounds for complete elliptic integrals of the second kind with applications, Comput. Math. Appl., 2012, 63(7), 1177-1184.

[23] Y.-M. ChU, M.-K. WANG, Y.-P. JIANG AND S.-L. QIU, Concavity of the complete elliptic integrals of the second kind with respect to Hölder means, J. Math. Anal. Appl., 2012, 395(2), 637-642.

[24] M.-K. WANG AND Y.-M. CHU, Asymptotical bounds for complete elliptic integrals of the second kind, J. Math. Anal. Appl., 2013, 402(1), 119-126.

[25] Z.-H. YANG, Y.-M. CHU AND W. ZHANG, High accuracy asymptotic bounds for the complete elliptic integral of the second kind, Appl. Math. Comput., 2019, 348, 552-564.

[26] M. VUORINEN, Hypergeometric functions in geometric function theory, In: Special Functions and Differential Equations (Madras, 1997), 119-126, Allied Publ., New Delhi, 1998.

[27] N. Elezović And L. Minoković, Asymptotic behavior of power means, Math. Inequal. Appl., 2016, 19(4), 1399-1412.

[28] J.-F. TIAN, M.-H. HA AND C. WANG, Improvements of generalized Hölder's inequalities and their applications, J. Math. Inequal., 2018, 12(2), 459-471.

[29] J.-F. TIAN, Y.-R. ZHU AND W.-S. CheUNG, n-tuple Diamond-Alpha integral and inequalities on time scales, Rev. R. Acad. Cienc. Exactas Fís. Nat. Ser. A Mat. RACSAM, 2019, 113(3), 2189-2200.

[30] X.-H. He, W.-M. Qian, H.-Z. XU And Y.-M. ChU, Sharp power mean bounds for two SándorYang means, Rev. R. Acad. Cienc. Exactas Fís. Nat. Ser. A Mat. RACSAM, 2019, 113(3), 2627-2638.

[31] R. W. BARNARD, K. PEARCE AND K. C. RICHARDS, An inequality involving the generalized hypergeometric function and the arc length of an ellipse, SIAM J. Math. Anal., 2000, 31(3), 693-699.

[32] H. AlZER AND S.-L. QIU, Monotonicity theorems and inequalities for the complete elliptic integrals, J. Comput. Appl. Math., 2004, 172(2), 289-312.

[33] M.-K. WANG, Y.-M. ChU, S.-L. QIU AND Y.-P. JIANG, Bounds for the perimeter of an ellipse, J. Approx. Theory, 2012, 164(7), 928-937.

[34] M.-K. WANG, Y.-M. ChU, Y.-P. JiAng AND S.-L. QIU, Bounds of the perimeter of an ellipse using arithmetic, geometric and harmonic means, Math. Inequal. Appl., 2014, 17(1), 101-111.

[35] G. D. Anderson, M. K. Vamanamurthy and M. Vuorinen, Conformal Invariants, Inequalities, and Quasiconformal Maps, John Wiley \& Sons, New York, 1997.

[36] C.-P. Chen And F. QI, The best bounds in Wallis' inequality, Proc. Amer. Math. Soc., 2005, 133(2), 397-401. 